\title{
KAJIAN PEDOMAN PELAKSANAAN PKP PGSD DAN PGPAUD UNIVERSITAS TERBUKA
}

\author{
Nana Setiana ${ }^{1}$
}

\begin{abstract}
ABSTRAK
Sejalan dengan perkembangan ilmu pengetahuan dan teknologi, guru di masa yang akan datang akan mendapat tantangan besar. Oleh sebab itu, dimasa depan guru harus lebih profesional dan sekaligus harus memenuhi standar minimal sebagai tenaga pendidik. Penetapan standar ini tentu saja berhubungan dengan tujuan pendidikan agar mampu menghasilkan sumber daya manusia yang handal, unggul, dan berdaya saing tinggi di masa yang akan datang.Guna mewujudkan guru yang memiliki kualifikasi standar tersebut telah pula dilakukan berbagai upaya. Salah satu upaya tersebut antara lain dilakukan melalui pendidikan dalam jabatan. Untuk guru PAUD dan SD, pendidikan dalam jabatan berupa perkuliahan formal antara lain dilakukan melalui Program S1 PGSD dan PGPAUD oleh berbagai perguruan tinggi yang mendapat legalisasi dari Depdiknas yang salah satunya adalah UT. Untuk mencapai tujuan akhir tersebut, guru PAUD dan SD yang menjadi mahasiswa UT diharuskan mengikuti program Pemantapan Kemampuan Profesional atau PKP sebagai sarana untuk menerapkan kompetensikompetensi yang didapat sepanjang proses pembelajaran sehingga mereka akan menjadi guru yang profesional. Sejalan dengan hal tersebut, pelaksanaan program PKP PGSD dan PGPAUD harus dilaksanakan secara tepat waktu dan tepat sasaran sehingga dapat mencapai tujuan yang diharapkan. Oleh sebab itu, UT telah mengeluarkan berbagai prosedur yang mengatur pelaksanaan program tersebut. Namun demikian masih ditemukan sejumlah prosedur yang tingkat implementasionalnya masih rendah.Guna meningkatkan daya implementasional prosedur tersebut perlu dilakukan berbagai upaya. Salah satu upaya tersebut adalah mengkritisi dan menyempurnakan prosedur tersebut. Penyempurnaan prosedur dimaksud mencakup seluruh prosedur yang dinilai kurang implementasional. Beberapa prosedur yang disempurnakan tersebut meliputi prosedur yang melibatkan peran mahasiswa, prosedur yang melibatkan peran UT, dan prosedur yang melibatkan peran UPBJJ UT Bandung.
\end{abstract}

Kata Kunci: Program PKP PGSD dan PGPAUD, Peran Mahasiswa, Peran UT, Peran UPBJJ, Prosedur Pelaksanaan Program.

\section{A. Pendahuluan}

Berdasarkan Undang-Undang Nomor 20 tahun 2003 tentang Sistem Pendidikan Nasional, pendidikan nasional dilaksanakan dalam berbagai jenjang pendidikan, baik formal maupun informal. Pendidikan formal di persekolahan dimulai dari di berbagai jenjang dari mulai Pendidikan Anak Usia Dini (PAUD), Pendidikan Dasar, Pendidikan Menengah, sampai Pendidikan Tinggi. Tujuan

\footnotetext{
${ }^{1}$ Dosen PGSD, FKIP UPBJJ UT Bandung
} 
umum dari semua jenjang pendidikan tersebut tertuang dalam UU 20/2003 tentang Sistem Pendidikan Nasional, Pasal 3, yakni "Pendidikan nasional berfungsi mengembangkan kemampuan dan membentuk watak serta peradaban bangsa yang bermartabat dalam rangka mencerdaskan kehidupan bangsa, bertujuan untuk berkembangnya potensi peserta didik agar menjadi manusia yang beriman dan bertakwa kepada Tuhan Yang Maha Esa, berakhlak mulia, sehat, berilmu, cakap, kreatif, mandiri, dan menjadi warga negara yang demokratis serta bertanggung jawab. Sejalan dengan tujuan ini, salah satu misi pendidikan nasional adalah membantu dan memfasilitasi pengembangan potensi anak bangsa secara utuh sejak usia dini sampai akhir hayat dalam rangka mewujudkan masyarakat belajar.

Sejalan dengan tujuan dan misi tersebut,pendidikan haruslah diarahkan bukan hanya untuk mencetak tenaga kerja untuk industri melainkan juga tenaga kerja yang mengoptimalkan kemampuan berpikir dalam menjalankan pekerjaannya. Hal ini berarti bahwa pendidikan haruslah diarahkan pada upaya menciptakan situasi agar siswa mampu belajar dan memiliki kemampuan berpikir tahap tinggi. Guna dapat mencapai fungsi di atas, pendidikan saat ini haruslah menekankan pada upaya pembentukan kompetensi kepada para siswa yang sekaligus berarti bahwa harus pula diikuti dengan perubahan radikal atas budaya mengajar saat ini (Harling-Dammon, 2005)

Kondisi di atas mengharuskan misi guru dalam melaksanakan pendidikan berubah dari menciptakan lulusan hanya untuk dunia industri menjadi lulusan yang siap untuk menghadapi pekerjaan yang mengutamakan kemampuan berpikir tingkat tinggi (Reece dan Walker, 2004). Hal ini berarti bahwa guru diharuskan mampu untuk mempersiapkan seluruh siswa agar memiliki kemampuan berpikir yang meliputi kemampuan menemukan masalah, menemukan, mengintegrasikan, dan menyintesis informasi, menciptakan solusi baru, dan menciptakan kemampuan siswa dalam hal belajar mandiri dan bekerja dalam kelompok(Pollard, A. 2005). Dengan demikian guru haruslah benar-benar mampu untuk menemukan cara untuk mendorong dan mengembangkan pemenuhan seluruh kebutuhan siswa berdasarkan potensi yang dimilikinya. Hal sejalan dengan apa yang diungkapkan Darling-Hammondet.al. (2006.)bahwa tanpa usaha ini akan sulit tercipta lulusan yang berbekal kemampuan berpikir tingkat tinggi.

Sejalan dengan kondisi di atas, guru di masa yang akan datang akan mendapat tantangan besar. Minimal ada tujuh tantangan besar bagi guru dalam konteks pendidikan global dan berkualitas. Ketujuh tantangan tersebut antara lain adalah bahwa guru harus mengajar dengan berorientasi pada (1) konstruksi makna, (2) pembelajaran aktif (3) akuntabilitas, (4) penggunaan teknologi, (5) peningkatan kompetensi siswa, (6) kepastian pilihan, dan (7) masyarakat multikultur (Arends, 2007: 7). Oleh karena itu wajarlah jika pemerintah telah menetapkan standar pendidik melalui Peraturan Pemerintah Nomor 19 Tahun 2005 tentang Standar Nasional Pendidikan yang mensyaratkan guru harus memiliki kualifikasi akademik pendidikan minimum diploma empat (D-IV) atau sarjana (S1). Penetapan standar ini tentu saja berhubungan dengan tujuan pendidikan agar mampu menghasilkan sumber daya manusia yang handal, unggul, dan berdaya saing tinggi di masa yang akan datang. 
Guna mewujudkan guru yang memiliki kualifikasi standar tersebut telah pula dilakukan berbagai upaya. Salah satu upaya tersebut antara lain dilakukan melalui pendidikan dalam jabatan. Untuk guru PAUD dan SD, pendidikan dalam jabatan berupa perkuliahan formal antara lain dilakukan melalui Program S1 PGSD dan PGPAUD oleh berbagai perguruan tinggi yang mendapat legalisasi dari Depdiknas. Salah satu perguruan tinggi yang menyelenggarakan Program S1 PGSD adalah Universitas Terbuka (UT) yaitu Fakultas Keguruan dan Ilmu Pendidikan (FKIP). Program S1 PGSD FKIP-UT merupakan program pendidikan dalam jabatan yang bertujuan untuk meningkatkan mutu dan kualifikasi guru PAUD dan guru kelas SD agar dapat mencapai kualifikasi S1. (UT, 2009).

Tujuan akhir Program S1 PGSD FKIP-UT adalah agar para lulusannya mampu berperan sebagai guru yang profesional. Lebih khusus, tujuan akhir Program S1 PGSD dan PGPAUDFKIP-UT yang mahasiswanya sudah menjadi guru di SD, difokuskan pada peningkatan kemampuan profesional tersebut, terutama didasarkan pada keluasan dan kedalaman wawasan yang dimiliki oleh guru sebagai landasan dalam mengambil keputusan, baik keputusan situasional ketika merencanakan pembelajaran maupun keputusan transaksional ketika melaksanakan pembelajaran. (UT, 2008).

Untuk mencapai tujuan akhir tersebut, guru PAUD dan SD yang menjadi mahasiswa harus dapat menerapkan kompetensi-kompetensi yang didapat sepanjang proses pembelajaran dari mulai semester awal hingga akhir. Desain bentuk penerapan kompetensi yang dimaksud tertuang dalam kurikulum Program S1 PGSD dan PGPAUD yaitu program Pemantapan Kemampuan Profesional atau PKP.

Secara garis besar bimbingan PKP meliputi empat tahap yaitu (1) persiapan dan pelaksanaan bimbingan orientasi PKP; (2) pelaksanaan bimbingan penyusunan Rencana Perbaikan Pembelajaran (RPP) dan praktik perbaikan pembelajaran; (3) pelaksanaan bimbingan pembuatan Laporan PKP; dan (4) pelaksanaan ujian praktik perbaikan pembelajaran.Kegiatan-kegiatan tersebut harus dilaksanakan dengan sebaik-baiknya oleh pembimbing (supervisor) PKP dan mahasiswa, sehingga terwujud pelaksanaan bimbingan PKP yang berkualitas.

Guna memfasilitasi pelaksanaan program PKP PGSD dan PGPAUD yang tepat pelaksanaan dan tepat sasaran, UT telah menetapkan sejumlah prosedur pelaksanaan PKP. Prosedur tersebut berfungsi sebagai pedoman pelaksanaan PKP sehingga mencapai tujuan utamanya yakni meningkatkan kompetensi dan profesionalisme guru. Prosedur yang telah ditetapkan tersebut memang telah mengatur seluruh aspek pelaksanaan PKP. Namun pada praktiknya di lapangan masih ditemukan sejumlah pemasalahan. Sejumlah permasalahan ini terungkap pada saat sosialisasi panduan sebagaimana yang diungkapkan para pelaksana teknis di lapangan.

Sejalan dengan kondisi ini, diperlukan sebuah kajian atas pedoman penyelenggaraan PKP PGSD dan PGPAUD. Kajian ini dimaksudkan untuk mengetahui beberapa kelemahan prosedur tersebut ditinjau dari kemungkinan implementasinya di lapangan. Selanjutnya berdasarkan hasil kajian ini akan dirumuskan beberapa alternatif praktis penyempurnaan pedoman pelaksanaan PKP tersebut sehingga tingkat implementasinya menjadi lebih tinggi. Pembahasan 
kajian akan dilakukan secara terintegrasi berdasarkan pihak-pihak yang terlibat dalam pelaksanaan program PKP PGSD dan PGPAUD.

\section{B. Peran Mahasiswa}

Mahasiswa merupakan subjek yang paling penting dalam pelaksanaan program PKP PGSD dan PGPAUD UT. Hal ini disebabkan oleh kenyataan bahwa mahasiswa adalah pelaku utama program tersebut sekaligus sasaran pelaksanaan program. Berdasarkan kenyataan ini, faktor utama yang menentukan keberhasilan program PKP PGSD dan PGPAUD UT adalah mahasiswa.

Dalam pelaksanaan PKP PGSD dan PGPAUD mahasiswa memiliki peran yang harus dilaksanakannya. Peran tersebut adalah (1) melakukan kegiatan refleksi pembelajaran, (2) menyusun rencana perbaikan pembelajaran, (3) melaksanakan praktik perbaikan pembelajaran, dan (4) menyusun laporan penelitian perbaikan pembelajaran. Berdasarkan perannya tersebut, mahasiswa yang mengikuti program ini harus bekerja keras guna dapat menyelesaikan program tersebut. Selain harus bekerja keras, mahasiswa juga dituntut menguasai konsep keilmuan secara lengkap yang meliputi konsep keilmuan kependidikan, konsep keilmuan bidang studi, dan konsep keilmuan penelitian.

Sejalan dengan kompleksnya peran mahasiswa, Pedoman penyelenggaraan PKP telah secara mendetail mengupas kegiatan apa saja yang harus dilakukan mahasiswa serta luaran apa saja yang harus dihasilkannya. Beberapa hal yang diatur tersebut meliputi (1) pedoman registrasi untuk mengikuti program PKP, (2) pedoman penyusunan laporan PKP, (3) pedoman penilaian praktik perbaikan pembelajaran, (4) pedoman penilaian laporan PKP, dan (5) pedoman penyusunan administrasi pelaksanaan PKP. Seluruh pedoman tersebut telah tercantum dengan jelas sehingga diharapkan mahasiswa tidak lagi mengalami kesulitan mengikuti program PKP.

Dari sejumlah pedoman tersebut, kenyataannya di lapangan pastilah akan ditemukan sejumlah masalah. Salah satu masalah utama berkenaan dengan penyusunan Rencana Pelaksanaan Pembelajaran (RPPa) dan penyusunan Rencana Perbaikan Pembelajaran (RPPb). Sebagaimana diketahui bahwa penyusunan RPP yang dilakukan para guru di sekolah memiliki tingkat keragaman yang tinggi. Berdasarkan tingkat keragaman ini dimungkinkan mahasiswa akan mengalami kesulitan untuk membuat RPP yang standar. Keberagaman yangmungkin muncul bukan hanya terletak pada format RPP melainkan juga keberagaman waktu pelaksanaan pembelajaran.

Berdasarkan kenyataan ini, pedoman yang telah ditetap UT dalam mengatur peran mahasiswa seyogyanya dilengkapi dengan penentuan standar RPPa maupun RPPb. Penentuan ini sangat penting terutama dalam alokasi waktu pembelajaran. Guna dapat melaksanakan penelitian perbaikan pembelajaran alokasi yang diperlukan minimal 2 jam pelajaran. Alokasi waktu sejumlah ini akan mampu menunjukkan peran siswa dalam seluruh tahapan pembelajaran sehingga pelaksanaan pembelajaran yang berbasis kinerja aktif akan dapat terlaksana secara optimal.

Guna mengantisipasi kondisi di atas, UT memang telah menyediakan supervisi 1 dan supervisor 2 yang bertugas membimbing mahasiswa. Keberadaan 
supervisor ini memang akan sangat membantu mahasiswa melaksanakan praktis pembelajaran. Namun di sisi lain keberadaan dua supervisor ini belum tentu mampu mengantisipasi munculnya masalah di atas, disebabkan oleh kenyataan bahwa di kalangan supervisor sendiri masih terdapat keberagaman pendapat tentang hal ini. Oleh sebab itu, pedoman penyusun RPPa dan RPPb tentang harus disusun oleh UT sebagai pengelola utama kegiatan PKP.

Selain pedoman penyusunan RPP, pedoman lain yang harus dipahami mahasiswa adalah pedoman pemilihan mata pelajaran khususnya untuk PKP guru SD. Dalam pedoman UT memang telah ada panduan yang memberikan kesempatan pada mahasiswa untuk memilih mata pelajaran eksak, noneksak, atau tematik. Namun penentuan mata pelajaran ini selayaknya dipandu oleh UT agar mahasiswa memilih mata pelajaran yang problematik bukan mata pelajaran yang dianggap mudah oleh mereka. Dalam keyakinan penulis, banyak di antara mahasiswa akan memilih mata pelajaran yang paling dianggap mudah sehingga jangan-jangan mata pelajaran tersebut sebenarnya bukanlah mata pelajaran yang harus diperbaiki pelaksanaannya. Selain itu, penelitian pembelajaran tematik juga tidak ada panduan secara jelas. Padahal berdasarkan konsep pembelajaran tematik, pembelajaran tematik dapat dilaksanakan dengan menggunakan beberapa tipe pembelajaran. Di Indonesia sendiri terdapat tiga tipe yang diakui yakni tipe jaring laba-laba, tipe koneksi, dan tipe integratif. Pelaksanaan ketika tipe ini tentu saja berbeda sehingga tidak akan terdapat keseragaman bentuk tematik mana yang harus digunakan mahasiswa terutama untuk kepentingan program PKP ini.

Guna mengantisipasi kemungkinan munculnya masalah ini, UT telah menentukan supervisor untuk membantu mahasiswa menentukan mata pelajaran dan melaksanakan penelitian. Namun demikian, para supervisor pun tentunya memiliki pandangan yang berbeda dalam menentukan mata pelajaran yang harus dipilih siswa. Dimungkinkan juga akan muncul supervisor yang menghendaki mahasiswa memilih mata pelajaran termudah dengan alasan agar praktiknya mudah dan lancar. Dalam kondisi ini mahasiswa akan mengalami melaksanakan praktik pembelajaran karena dimungkinkan siswa sudah berhasil pada tahap prasiklus. Kalau hal ini terjadi, esensi perbaikan pembelajaran tidak akan tercapai secara optimum dan yang paling ditakutkan adalah terjadinya manipulasi data. Oleh sebab itu sebaiknya UT secara tegas menekankan bahwa mata pelajaran yang dipilih hendaknya mata pelajaran tersulit bagi siswa atau mata pelajaran yang sebagian besar siswanya belum memenuhi standar kelulusan.

Selain dalam penentuan mata pelajaran, penentuan pembelajaran tematik pun seyogyanya diatur oleh UT. Beragam bentuk pembelajaran tematik pastilah akan membingungkan para mahasiswa. Jika saja mahasiswa menentukan pembelajaran tematik integratif misalnya, mahasiswa tentu harus meneliti tiga mata pelajaran sekaligus. Padahal masing-masing mata pelajaran memiliki keunikan sehingga strategi pembelajarannya pun akan sangat berbeda. Bentuk tematik semacam ini selaian menuntut pelaksanaan pembelajaran yang benarbenar tidak ada batas pemisah antar mata pelajaran juga akan menuntut evaluasi yang kondisinya sama. Dengan demikian penelitian perbaikan yang dilakukan siswa cenderung lebih sulit. Sebaliknya jika yang dipilih adalah tematik koneksi penelitian yang dilakukan kurang mencerminkan keterpaduan mata pelajaran. 
Sejalan dengan kondisi ini selayaknya UT secara tegas menentukan jenis tematik jaring laba-laba (webbed) yang harus dipilih mahasiswa sehingga pada praktiknya mahasiswa dapat memfokuskan diri untuk meneliti satu mata pelajaran dalam kesatuan tema yang dipilih.

Demikianlah beberapa hal yang harus diperhatikan UT ke depan agar pelaksanaan program PKP lebih lancar. Seluruh uraian ini memang masih sebatas hipotesis yang sebenarnya harus dibuktikan melalui penelitian secara lebih mendalam.

\section{Peran UT}

Pihak kedua yang terlibat dalam pelaksanaan program ini adalah UT sebagai penyelenggara kegiatan. Dalam konteks ini UT telah secara optimal merancang sejumlah prosedur pelaksanaan program dari tahap perencanaan hingga tahap evaluasi program. Hal ini dapat diketahui lewat telah tersedianya berbagai prosedur pelaksanaan program PKP baik untuk PGSD maupun untuk PGSD.

Pedoman yang telah dihasilkan UT memang telah bersifat seimplementatif mungkin. Beberapa prosedur tersebut antara lain (1) prosedur tahapan kegiatan PKP, (2) prosedur rekap nilai, (3) prosedur penilaian dan pengolahan nilai laporan PKP, (4) sistematika laporan PKP, (5) lembar pengesahan PKP, (6) lembar anti plagiat, (7) lembar kesediaan supervisor dan pernyataan mahasiswa, (8) jurnal pembimbingan, (9) format pelaksanaan praktik pembelajaran, (9) format APKG 1 dan 2, dan (10) jadwal praktik perbaikan pembelajaran. Selain itu UT juga telah membuat ketentuan tentang supervisor 1 dan supervisor 2 serta pedoman kinerja kedua supervisor ini.

Dalam praktiknya sejumlah pedoman tersebut masih harus mendapatkan penyempurnaan implementasionalnya. Beberapa pedoman yang masih harus mendapatkan penyempurnaan tersebut antara lain waktu penentuan penilaian praktik pembelajaran. Dalam pedoman yang dibuat UT belum jelas kapan pelaksanaan penilaian praktik pembelajaran dilaksanakan. Penentuan yang belum jelas ini harus disempurnakan. Penentuan waktu yang tepat untuk melaksanakan praktik perbaikan pembelajaran adalah pada saat siklus ke-2 atau pada saat kegiatan mandiri 2. Saat ini dikatakan paling tepat sebab pada saat tersebut mahasiswa sudah menguasai model atau metode pembelajaran yang dipilihnya sehingga akan terlihat benar ada atau tidaknya perubahan proses pembelajaran yang dilaksanakan.

Pedoman kedua yang harus dikritisi adalah tata cara pengumpulan nilai praktik. Dalam panduan awal UT, tidak terdapat ketentuan tata cara menyerahkan nilai hasil praktik pembelajaran dari penilai kepada supervisor 1. Belum jelasnya tata cara ini memungkinkan penilaian partisipasi yang seharusnya diberikan supervisor 1 akan terhambat bahkan mungkin saja tidak terlaksana tepat waktu. Sejalan dengan hal tersebut, harus dilakukan kepastian penyerahan nilai ini dan sekaligus ditentukan tata caranya. Sejalan dengan hal tersebut ditetapkan bahwa nilai praktik dikumpulkan kepada PJPM untuk diserahkan kepada supervisor 1. Penetapan PJPM disebabkan oleh kenyataan bahwa PJPM akan turun langsung ke lapangan pada saat proses penilaian berlangsung sehingga nilai dapat langsung 
diambil PJPM. Dari PJPM nilai tersebut diyakini sampai pada super 1 tepat waktu sehingga supervisor 1 dapat segera melakukan penilaian. Setelah supervisor 1 memberikan penilaian nilai kembali diserahkan kepada PJPM saat itu juga dan dari PJPM langsung diserahkan kepada UPBJJ. Ketepatwaktuan pengolahan nilai praktik ini akan menentukan keberhasilan program secara keseluruhan secara tepat waktu pula.

Panduan pelaksanaan orientasi yang di keluarkan UT juga perlu dikritisi. Dalam panduan tercantum bahwa pelaksanaan orientasi dihadiri oleh supervisor 1 dan mahasiswa. Dalam praktiknya di lapangan kondisi ini sangat tidak memungkinkan sebab mahasiswa tersebar di berbagai wilayah demikian pula supervisor 1. UT memang telah mengantisipasi hal ini dengan melaksanakan kegiatan pada pertemuan ke satu. Namun demikian jika kegiatan ini dilaksanakan pada kegiatan pembimbingan kesatu dapat dibayangkan akan banyak waktu terbuang untuk kegiatan tersebut. Padahal dalam pertemuan kesatu antara mahasiswa dan supervisor 1 , supervisor 1 harus melakukan orientasi PKP, menjelaskan refleksi pembelajaran, dan beberapa kegiatan penting lainnya. Dengan demikian jika orientasi dilaksanakan pada pertemuan kesatu akan banyak kegiatan penting yang tidak akan terlaksana dengan baik. Sejalan dengan prediksi tersebut, kegiatan orientasi dilaksanakan dengan hanya menghadirkan supervisor 1 dan 2 dan diselenggarakan di luar pertemuan bimbingan oleh UPBJJ. Penyelenggaraan kegiatan yang diatur sedemikian rupa ini tidak akan mengorbankan waktu bagi mahasiswa untuk mendapat berbagai informasi penting tentang pelaksanaan PKP pada pertemuan pertamanya dengan supervisor 1 .

Panduan pengelompokan mahasiswa yang diatur UT mengharapkan mahasiswa dikelompokkan oleh supervisor 1. Pengelompokan ini diharapkan dapat lebih efektif dilakukan agar mampu menjamin tercapainya aturan mahasiswa dibimbing berdasarkan supervisor 1-nya. Namun dalam praktiknya di lapangan, pengelompokan semacam ini akan banyak menghadapi kendala. Selain akan memakan waktu yang panjang pada pertemuan pertama, pengelompokan ini akan mengubah komposisi kelas yang sudah terbentuk di pokjar masing-masing. Sejalan dengan kenyataan tersebut, pengelompokan harus dilakukan sebelum proses pembimbingan yang dilakukan oleh pengelola pokjar dengan tetap mempertimbangkan pengelompokan berdasarkan supervisor 1. Pengelompokan dengan teknis semacam ini lebih efektif dan akan menghasilkan kelompok yang lebih tepat dan fleksibel dan efisien dari segi waktu.

Pedoman lain yang perlu dikritisi adalah pedoman penilaian praktik. Dalam pedoman yang dikeluarkan UT memang telah ada panduan tentang bagaimana menilai. Namun demikian panduan ini masih perlu penyempurnaan terutama tentang bagaimana mengubah skor ke dalam bentuk nilai. Penyempurnaan panduan ini sangat penting agar tidak terdapat kesalahan dalam menentukan nilai akhir. Oleh sebab itu, pedoman pengubahan skor ke nilai yang sifatnya standar perlu dilakukan. Selain itu, sejalan dengan tuntutan bahwa format penilaian tidak boleh kotor dan besar dari coretan seyogyanya disediakan pula lembar penilaian sementara. Lembar ini sangat penting untuk menghindari kesalahan baik yang dilakukan oleh supervisor 2 atau pun oleh supervisor 2 . 
Demikianlah beberapa hal yang harus diperhatikan UT agar penyelenggaraan program PKP menjadi lebih baik. Kajian kritis ini diharapkan mampu meningkatkan mutu dan layanan UT bagi mahasiswa sehingga mahasiswa benar-benar meningkat kemampuannya baik dalam hal melaksanakan praktik pembelajaran maupun dalam hal penyusunan laporan penelitian perbaikan pembelajaran. Keberhasilan ini lebih lanjut diharapkan akan mampu menjadikan mahasiswa tersebut seorang guru yang mampu menghadapi berbagai tantangan guru ke depan.

\section{Peran UPBJJ UT Bandung}

UPBJJ UT Bandung memiliki peran yang sangat penting dalam melaksanakan kegiatan PKP baik PGSD maupun PGPAUD. Beberapa peran penting tersebut di antaranya memfasilitasi mahasiswa dengan supervisor 1 dan 2 yang kompeten, mengontrol pelaksanaan PKP PGSD dan PGPAUD di lapangan, mengoreksi dan memperbaiki berbagai kesalahan prosedural yang mungkin terjadi, serta melaksanakan penilaian laporan secara tepat waktu, valid, dan reliabel.

Berdasarkan beberapa peran di atas, UPBJJ UT Bandung telah melakukan berbagai kegiatan esensial dalam menyukseskan pelaksanaan PKP PGSD dan PGPAUD. Beberapa kegiatan esensial tersebut meliputi kegiatan (1) pendataan mahasiswa peserta program, (2) menentukan supervisor 1 dan 2 yang kapabel di bidangnya, (3) melaksanakan orientasi PKP kepada supervisor 1 dan 2, (4) memfasilitasi pembentukan kelompok, (5) pembentukan kelas tutorial, (6) penyusunan jadwal praktik pembelajaran dan pelaksanaan tutorial, (7) memfasilitasi penyusunan RAT dan SAT oleh supervisor 1, (8) menyediakan berbagai administrasi pelaksanaan program, (9) memfasilitasi pelaksanaan kegiatan PKP PGSD dan PGPAUD , (10) menentukan metode dan pelaksanaan monitoring kegiatan, dan (11) melakukan penilaian dan pengolahan nilai baik praktik maupun laporan PKP.

Sejalan dengan sejumlah peran di atas, UPBJJ UT Bandung telah mengembangkan berbagai paduan yang dibuat UT Pusat. Berbagai pengembangan pedoman tersebut telah dibahas pada kedua bagian di atas. Satu pedoman yang belum dibahas adalah pedoman Monitoring pelaksanaan program. Dalam hal ini UT pusat belum menentukan monitoring termasuk belum menentukan standar baku pelaksanaan dan format monitoring yang seharusnya digunakan.

Sejalan dengan kenyataan tersebut, UPBJJ UT Bandung telah mengembangkan standar baku monitoring dan format monitoring yang harusnya digunakan. Standar baku tersebut mengatur tentang kapan waktu Monitoring dilaksanakan, berapa kali pelaksanaannya, dan aspek apa saja yang harus dimonitor serta format yang bagaimana yang dapat digunakan dalam kegiatan monitoring. Kegiatan monitoring dilaksanakan minimalnya dua kali yakni monitoring terhadap pelaksanaan pembimbingan oleh supervisor 1 dan monitoring pelaksanaan ujian praktik.

Monitoring terhadap proses pembimbingan terutama untuk mengetahui keterlaksanaan proses pembimbingan sesuai dengan prosedur yang telah ditetapkan. Aspek yang amati meliputi kelengkapan administrasi kegiatan 
pembimbingan, proses pembimbingan, serta ketercapaian tujuan pembimbingan. Monitoring terhadap pelaksanaan praktik ditujukan untuk mengetahui kelengkapan administrasi pelaksanaan praktik perbaikan pembelajaran, tempat pelaksanaan kegiatan praktik pembelajaran, proses pelaksanaan perbaikan pembelajaran, dan ketercapaian tujuan pelaksanaan kegiatan.

Sejalan telah ditetapkannya prosedur pembimbingan diharapkan kegiatan PKP PGSD dan PGPAUD ini dapat berjalan dengan lebih baik serta mampu mencapai hasil yang diharapkan. Ke depan berbagai terobosan lain yang berfungsi meningkatkan mutu pelaksanaan PKP PGSD dan PGPAUD ini akan terus dilakukan. Semua hal ini dilakukan agar proses penciptaan guru yang profesional benar-benar bisa terwujud. Akhirnya, UT berharap menjadi bagian penting bagi pengembangan profesionalisme guru Indonesia.

\section{E. Kesimpulan}

Pelaksanaan program PKP PGSD dan PGPAUD harus dilaksanakan secara tepat waktu dan tepat sasaran sehingga dapat mencapai tujuan yang diharapkan. Sejalan dengan tuntutan ini UT telah mengeluarkan berbagai prosedur yang mengatur pelaksanaan program tersebut. Namun demikian masih ditemukan sejumlah prosedur yang tingkat implementasionalnya masih rendah.

Guna meningkatkan daya implementasional prosedur tersebut perlu dilakukan berbagai upaya. Salah satu upaya tersebut adalah mengkritisi dan menyempurnakan prosedur tersebut. Penyempurnaan prosedur dimaksud mencakup seluruh prosedur yang dinilai kurang implementasional. Beberapa prosedur yang disempurnakan tersebut meliputi prosedur yang melibatkan peran mahasiswa, prosedur yang melibatkan peran UT, dan prosedur yang melibatkan peran UPBJJ UT Bandung.

Sejalan telah ditetapkannya sejumlah penyempurnaan prosedur pelaksanaan kegiatan PKP PGSD dan PGPAUD, program ini dapatberjalan secara optimal. Akhirnya usaha mewujudkan guru yang profesional melalui UT bukanlah hal yang sekadar dicita-citakan melainkan benar-benar terlaksana. Hal ini sangat penting untuk mengokohkan UT menjadi universitas kelas dunia khususnya dalam penyelenggaraan program pendidikan jarak jauh.

\section{DAFTAR PUSTAKA}

Arends, R.I. 2007. LearningtoTeach. New York: McGraw Hill Companies. Darling-Hammond. dan Bransford (Ed.).2005 PreparingTeachers for a Changing World. San Francisco: Jossey-BassPublishing.

Darling-Hammond. Et.al. 2006. PowerfulTeacher Education. San Francisco: Jossey-BassPublishing.

Departemen Pendidikan Nasional. (2003). Undang-Undang Republik Indonesia Nomor 20 Tahun 2003 Tentang Sistem Pendidikan Nasional. Jakarta: Depdiknas

Departemen Pendidikan Nasional. (2005). Peraturan Pemerintah Republik Indonesia Nomor 19 Tahun 2005 Tentang Standar Nasional Pendidikan. Jakarta: Depdiknas 
Pollard, A. 2005. Reflektif Teaching. London: Continuum.

Reece dan Walker. 2004. Teaching, Training, andLearning. Great Britain: Business Education Publishing Limited.

Universitas Terbuka. (2009). Katalog Program Pendas. Jakarta: Universitas Terbuka

Universitas Terbuka. 2008. Panduan Pemantapan Kemampuan Profesional. Jakarta: Universitas Terbuka 